\title{
Culture, Language, and Knowledge: Cultural Learning Styles for International Students Learning Chinese in China ${ }^{*}$
}

\author{
Lynne N. Li \\ Xiao Wang \\ RMIT University, Melbourne, Australia \\ Chongqing University of Technology, Chongqing, China
}

\begin{abstract}
This article reports on a study that attempts to examine the cultural learning styles of international students learning Chinese in China and their engagement in activities associated with linguistic and cultural knowledge. By drawing upon the previous research around cultural dimensions of learning styles and knowledge transmission and sharing, this paper explores the impact of cultural differences on Chinese language learning and on the level of engagement in activities involving multicultural and multilingual knowledge. Through looking at the Chinese learning experiences of international students coming from Asian countries, this study showcases how the learners' cultural styles of learning interact with their existing cultural and linguistic knowledge during their Chinese language learning in the target learning context. It is expected that this study will inform future research on cultural learning styles and knowledge exchange and sharing among Chinese learning students. The findings will have implications for language practitioners and educators to be upfront with linguistic and cultural diversity over the course of their education practices and to unleash the power of knowledge this diversity distinctively entails. This study will also shed light on the research and best practices in learning and teaching of Chinese language and other languages and cultures.
\end{abstract}

Keywords: cultural learning styles, multicultural knowledge, multilingual knowledge, knowledge transmission and sharing, Chinese language learning

\section{Introduction}

The close association between culture and learning in today's world endows people from different cultural backgrounds with a knowledge base which they can use to enrich their learning and interaction with people from backgrounds that are different from theirs. This endowment is well reflected in the process of language learning. In today's globalized knowledge society, language learners are becoming more and more multilingual and multicultural; so are the contexts in which they are living and learning; and so is the knowledge base they are endowed with.

This multilingual and multicultural knowledge is often transmitted and shared among geographically,

\footnotetext{
* Acknowledgement: This article is based on an extended project for the Trans-national Knowledge Network in Education that was funded by Australian Learning and Teaching Council. We take this opportunity to thank the academics at RMIT University in Australia and Chongqing University of Technology who have been working vigorously on this collaborative project and the students at Chongqing University of Technology who generously contributed their time to participating in this research.

Lynne N. Li, Ph.D., lecturer and coordinator of Chinese language studies, School of Global Studies, RMIT University.

Xiao Wang, associate professor, English and Chinese Languages Department, Chongqing University of Technology.
} 
linguistically, culturally, and ideologically dispersed individuals. Second and foreign language learning ${ }^{1}$ is an integral part of this learning and sharing experience. Knowledge sharing and knowledge transmission have been widely explored for decades in the research area of knowledge management (e.g., Hedlund, 1994; Hedlund \& Nonaka, 1993; Nonaka \& Takeuchi, 1995; Holden, 2002; Chini, 2004; Haghirian, 2011). Few research studies have brought the process of knowledge transmission into second language acquisition, nor into cultural dimensions of learning styles (Kommers \& Venbrux, 2008).

This current study draws together the research frameworks of second language acquisition on learning styles, cultural studies, and knowledge management. In particular, Hofstede's $(1980 ; 1986 ; 2001)$ cultural differences in learning and Ipe's (2003) theoretical framework on knowledge sharing and transmission are brought into examination in order to explore the cultural learning styles of a group of Chinese language learners who have originally come from Asian cultural backgrounds and their engagement in activities involving linguistic and cultural knowledge transmission and sharing.

\section{Literature Review}

The connection between culture and language learning has been well researched for the past hundred years. The earlier endeavors can be represented by Sapir (1921) and Whorf (1956), with later ones including Brown (1973; 1980), Oxford (1990), Willing (1993; 1998), Reid (1995), and Ellis (1997). It has been commonly acknowledged amongst linguistic and social-linguistic theorists that one's native language is both a reflection of one's culture and vice versa (e.g., Hofstede, 1980; Brown, 1980).

Research into the learning styles, including that of language learners, has been extensive, involving behavioural, cognitive, physiological, biological, affective, and cultural dimensions. Evidence for this is abundant, spanning from the 1970s to more recent days (e.g., Kogan, 1971; Goodenough, 1976; Kolb, 1976; Witkin, 1976; Witkin \& Goodenough, 1977; Keefe, 1979; 1987; Dunn \& Griggs, 1988; Myers, McCaulley, Quenk, \& Hammer, 1998; House, Hanges, Javidan, Dorfman, \& Gupta, 2004; G. Hofstede \& G. J. Hofstede, 2005). As researchers at different time periods have approached learning styles from many different perspectives and various dimensions, for the purposes of this study, we focus only on one dimension of learning styles: the cultural learning styles (Hofstede, 1980; 1986; 2001; Willing, 1998; Reid, 1995; Joy \& Kolb, 2009).

Though he focuses more on cultural differences in business organisations, Hofstede has as well explored cultural differences in learning contexts. Through his research on work-related values in over 50 countries, Hofstede developed four dimensions of cultural differences amongst societies: Individualism vs. Collectivism, Large vs. Small Power Distance, Strong vs. Weak Uncertainty Avoidance, and Masculinity vs. Femininity (Hofstede, 1980; 1991; 2001).

Hofstede brought the national differences into the relationship of teacher and student in the classroom with two of his four dimensions: Collectivism vs. Individualism and Large vs. Small Power Distance. Hofstede

\footnotetext{
${ }^{1}$ Second language learning differs from foreign language learning in language acquisition inquiry. If the language learning takes place in a native Chinese-speaking country, such as learning Chinese in China, it is regarded as Chinese learning as a second language. If Chinese learning happens in a non-native Chinese-speaking country, such as in Australia, it is regarded as Chinese learning as a foreign language. However, in today's globalised world, as language learning is often quoted in an analogy as obtaining a "passport" to travel/work/migrate to other countries, many learners acquire new languages in different contexts at various stages of their learning. It becomes increasingly difficult to differentiate learning by contexts. It is then for the convenience of this discussion that both "second language learning" and "foreign language learning" are used interchangeably in this paper, with both referring to the experience of taking on a new language.
} 
(1986) believed that the teacher-student relationship is "an archetypal role pair in virtually any society" (p. 301), and is deeply rooted in the culture of a society. The teacher-student interaction in the classroom and their differences are reflected in the way that Collectivism and Large Power Distance are associated with an Eastern style of learning, whereas Individualism and Small Power Distance are associated with a Western style of learning $^{2}$. In the context of teaching and learning, the two dimensions - Collectivist vs. Individualist and Large Power Distance vs. Small Power Distance - are interpreted as the teacher-student relation featuring traditional vs. non-traditional, teacher-centered $v s$. student-centered, formal vs. informal, and competition $v s$. cooperation (Hofstede, 1986; Tobin, Wu, \& Davidson, 1989; Tweed \& Lehman, 2002; Rao, 2003).

Let's take Singapore for example. As Singapore is an Asian country, in the relation between teachers and students in the classroom, Singaporean students are believed to be characterised as representing an Eastern or Asian style of learning, as being traditional, teacher-centered, formal, and more cooperative than competitive. Australian students, in contrast, show the features of a Western style of learning, being non-traditional, student-centered, informal, and more competitive than cooperative.

In language learning situations, if more focus is given to literacy skills development and the teaching is more teacher-centered, then it is more an Asian style of learning (Hofstede, 1986; Chen, 1990). The Western style of learning lays more weight on the communicative competence of language and student-centered teaching in the classrooms (Canale \& Swain, 1980; Canale, 1983; 1984; Nunan, 1988). According to Canale and Swain (1980), communicative competence of language often involves social-linguistic competence, grammatical competence, discourse competence, and strategic competence, all of which aim for effective communication skills of the learners.

Early in the 1980s, Hofstede $(1980 ; 1986)$ noted that cultural differences play a role in cross-cultural learning and that language is an important factor in cross-cultural teacher-student interaction. Since then, there have been abundant research studies that continue to bring his theoretical framework to other studies involving cultural differences (e.g., Tobin et al., 1989). A large-scale study involving 9,400 airline pilots in 19 different countries (Merritt, 2000) has made prime application of the Hofstede framework 20 years after the original study. The most recently refreshed studies could include House and his international collaborators (House et al., 2004), Hofstede and his colleagues (G. Hofstede \& G. J. Hofstede, 2005), Kolb and his team (Joy \& Kolb, 2009), and Bengoa (2013).

Furthermore, there has been a recent emphasis on language learning and teaching in cross-cultural interactions and international business. Some researchers find that second language learning and teaching are being treated as economic commodities (Heller, 1999; Friedman, 1994; Park \& Wee, 2013). Some researchers claim that multiple linguistic skills of workers at all levels of business management take on new importance in today's multilingual knowledge economies (Cameron, 2000; 2005; Erreygers \& Jacobs, 2005). Other researchers assume that the new communication skills and multiple literacies required by ever-advancing technologies are gaining ground (Cope \& Kalantzis, 2000; Li, 2000; 2012). This multilingual and multicultural competence is seen as valuable "linguistic capital" in the world's multilingual knowledge economies (Bourdieu,

\footnotetext{
${ }^{2}$ Some scholars can debate whether or not the ideological boundaries between "East" and "West" are fading as a result of globalisation. This paper opts for the traditional collocations of these terminologies not only because this current study employs Hofstede's theory of four dimensions of cultural differences, but also because many researchers today are still fascinated by the distinction between Collectivism vs. Individualism (e.g., Ardichvili, Maurer, Li, Wentling, \& Stuedmann, 2006; Bengoa, 2013). Joy and Kolb (2009) claimed that this fascination to Collectivism vs. Individualism to differentiate between cultures is evident "to the extent that both scholars and laymen often think of it as the only way to explain cultural differences" (p. 73).
} 
1991), a means of promoting intercultural competence (Lo Bianco, Liddicoat, \& Crozet, 1999) and even a symbolic weapon for political power (Phillipson, 1992; 2002).

It makes sense that in business and multinational organizations, knowledge transmission and sharing has been researched vigorously for the past few decades (e.g., Hedlund, 1994; Nonaka \& Takeuchi, 1995; Bresman, Birkinshaw, \& Nobel, 1999; Holden, 2002; Ipe, 2003; Chini, 2004; Haghirian, 2011). For the past few years, the interest and attention of knowledge transfer in knowledge management has stretched beyond the business world to other disciplinary areas, including learning and teaching in educational institutions (e.g., Howard, 2005; Robinson, 2010; Smith, 2012). Howard (2005) commissioned a research project on knowledge transfer, which sets out the background and highlighted the value of making connections with intellectual knowledge; he taps the trend of knowledge flow among individuals and organizations with "The Emerging Business of Knowledge Transfer" as the book title (Howard, 2005).

This study is another attempt to bring knowledge transfer or transmission into education institutions. Language learners are constantly engaged in the transmission of the linguistic and cultural knowledge that is embedded in their native language and that of the newly acquired language. On the basis of the previous theoretical frameworks on knowledge transmission and sharing in knowledge management and cultural learning styles in language studies, this current study makes an exploratory attempt to draw on the connections among culture, language, and knowledge in international Chinese language education. For this current study, Hofstede's $(1980 ; 1986)$ cultural learning styles will be examined with two of its four dimensions: Collectivist vs. Individualist Cultures and Large Power Distance vs. Small Power Distance. Ipe's (2003) individual knowledge transfer model will be brought into focus with its four influential factors that impact on knowledge transmission: (a) the nature of knowledge; (b) opportunity to share; (c) motivations to share; and (d) the culture of the work environment and their relationships. Each individual participant's Chinese language learning will be put in a microcosm multilingual and multicultural knowledge society, in this case, a university in China, within which these individuals are operating by engaging in knowledge transmission and sharing and learning activities both inside and outside classrooms.

\section{Method}

The principal aim of this project is to identify the cultural learning styles of a group of Chinese language learners from Asian countries, and examine how these cultural learning styles interact with the participants' participation in knowledge transmission activities. The research participants are 35 fee-paying international learners of Chinese from a university in China: 16 Byelorussian (45.8\%), five Russians (14.2\%), and 14 Vietnamese (40\%). They came to China to complete a program as part of their career plans or part of their travel arrangements. This study focused on beginners and intermediate level of Chinese: 22 (62.9\%) intermediate participants and $13(37.1 \%)$ beginning learners. Their age ranges from 18 to 25 years old, with the average age being 21 , and more than $80 \%$ of them being within the range of 19-22 years old. Twenty-two $(62.9 \%)$ of the participants are females and $13(37.1 \%)$ are males. Almost all have registered for a 30 -week program with only one exception.

The major source of participants for this study—Byelorussian, Russians, and Vietnamese-were not included in the original Hofstede's (1980) study on national cultures. In the public domain, there has been controversy as to whether Russia and Byelorussia are part of Asia or part of Europe. In research practices, researchers tend to categorize them as part of Asia, as they tend to hold the view that Russian or Byelorussian 
learners share cultural values closer to those of Asian learners (e.g., Ardichvili et al., 2006; Bengoa, 2013). Hofstede's (1980) original study also did not include Vietnamese nationality, but Vietnamese comes under the aegis of the Confucian ethic which most of the East Asian countries share-such as Hongkong, Singapore, Thailand, Korea, and Japan (Biggs \& Watkins, 1996). For the purposes of this research study, the learning of Chinese language of the Russian, Byelorussian, and Vietnamese participants will be examined against the cultural norm of Asian learners.

Cultural learning styles are assessed through a questionnaire entitled Cultural Learning Styles Inventory (CLSI), which was adapted from Hofstede's (1986) framework on cultural differences in classroom learning. The features of cultural differences in learning are assessed in an instrument of 46 forced-choice options whereby students were required to choose one of two paired statements that best expressed their values or opinions. The score for the Collectivism/Individualism was obtained through the Collectivism score minus the Individualism score, and the score of Power Distance was obtained through the Small Power Distance score minus the Large Power Distance score, in accordance with the cultural differences index of Hofstede's (1980; 1986) original study as the increase of one directly infers the decrease for the other on the same axis (see Figure 1 in the Section "Results and Analysis").

Knowledge transmission and sharing is assessed through a questionnaire entitled Cross-Cultural Knowledge Transfer (CCKT), which was designed in light of previous research studies on knowledge management and knowledge transfer. In particular Ipe's (2003) model of individual knowledge transfer was employed as the theoretical framework for designing the research questionnaire, which is structured into three sections: 1 . Understanding and engaging in CCKT activities outside classrooms; 2. Understanding and engaging in CCKT activities within classrooms; and 3. Self-evaluating their own understanding and participation in CCKT activities. For each section, the questionnaire has listed numerous items of activity for the participants to respond to, through answering questions relating to: 1 . If they think these activities have aspects of CCKT; 2 . If they participate in these activities; and 3. How often they participate in these activities. The participants' understanding of what multilingual and multicultural knowledge is and their evaluation of their own engagement in activities involving such knowledge compose an integral part of this assessment.

All items were presented in question format, with a list of choices for participants to choose from. Some questions allow participants to choose as many items as they wished, and some questions narrowed their choices down to only one or three options. Though all the responses are in the form of numerical numbers, they as well posit quantitative nature as each question lists out choices for participants to choose from. The questionnaire was originally in English and was subsequently translated into the native languages of the participants, and in some cases into Chinese language in order to make sure that the participants understood fully the content of the questionnaire and to adequately control the validity and reliability of the data.

While the term "knowledge transfer" generally focuses more on the outcomes of knowledge generation and sharing, the term "knowledge transmission" relates more to the learning processes that run throughout knowledge creation and learning (Duan, Nie, \& Coakes, 2010). As this research study involves more the processes of learning through knowledge generation and sharing, "knowledge transmission" is the preferred terminology in this paper. However, "knowledge transfer" remains as the title of the questionnaire as we anticipated "knowledge transfer", being a more general and straightforward term, would be easier for the participants to understand. 
Data analysis aims to identify: (a) any tendencies and the frequency of students' participating in activities that have multilingual and multicultural knowledge embedded in; (b) predictors of successful knowledge transmission; and (c) possible correlation coefficients among the indices. Data analysis is through both Statistical Package for Social Sciences (SPSS) statistical procedures and content analysis.

\section{Results and Analysis}

\section{Cultural Learning Styles}

Table 1 presents the descriptive data from the CLSI for Hofstede's (1986) two cultural dimensions: Collectivism vs. Individualism and Large Power Distance $v s$. Small Power Distance. The mean for Collectivism $v s$. Individualism for this dimension is -2.43 , and that for Large Power Distance vs. Small Power Distance is 0.09; these results mean that this group of participants are more individualist, and with smaller power distance.

Table 1

Descriptive Data Obtained From the CLSI

\begin{tabular}{llll}
\hline & & Collectivism vs. Individualism & $\begin{array}{l}\text { Large Power Distance } v s . \\
\text { Small Power Distance }\end{array}$ \\
\hline \multirow{4}{*}{ Central tendency dispersion } & Valid cases & 35 & 35 \\
& Missing & 0 & 0 \\
& Mean & -2.43 & 0.09 \\
& $S D$ & 3.407 & 3.442 \\
\hline
\end{tabular}

Figure 1 presents the results in a grid adapted from Hofstede's (1986). The scores are expressed in standard grid format with positive scores on one end and negative scores on the other. On the horizontal axis of Collectivism/Individualism, a highly positive score means a high level of collectivist culture whilst a highly negative score indicates a high level of individualist culture. On the vertical axis of Large/Small Power Distance, a highly positive score means small power distance whilst a highly negative score points to large power distance.

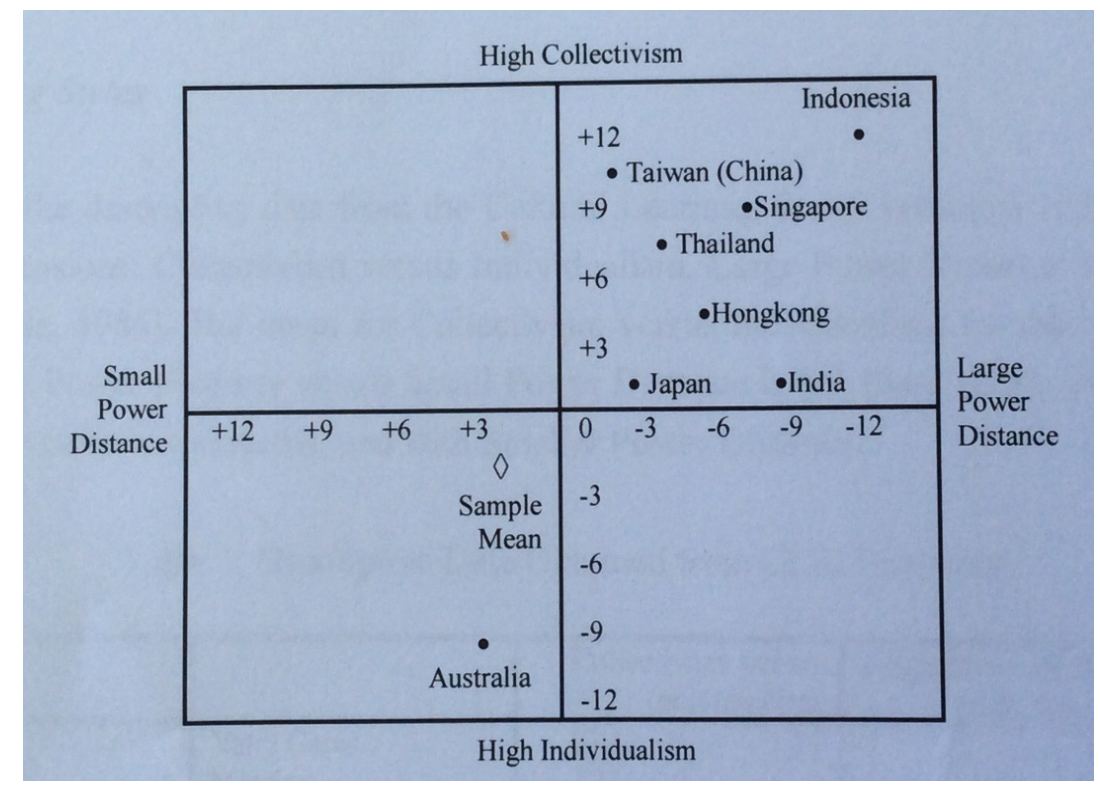

Figure 1. Mean scores for dimensions of cultural learning styles, by country. 
Hofsdede's $(1980 ; 1986)$ research plots the 50 participating countries on the axis of Large/Small Power Distance against Individualism/Collectivism. It is immediately clear how some countries-Australia and a number of Asian countries as cited example cases - are situated in the coordinate grid against the examined parameters: Asian countries fall clearly in the upper right quadrant of the coordinate grid; Australia falls into the lower left quadrant.

From the grid, it is evident that the learning styles of participants, indicated with a diamond, have moved considerably away from the Eastern styles of learning, into the bottom-left quadrant of the Western "territory", closer to the norm of Australia, but still hanging on to the top corner of the grid. This shows that the learners of Chinese language demonstrated more features of individualist way of learning that is more student-centered and more communication-oriented, but still close to their cultural norm.

\section{Cross-Cultural Knowledge Transmission and Sharing}

The data summary for CCKT follows the structure of the questionnaire in three sections, i.e., 1. Understanding and engaging in CCKT activities outside classrooms; 2. Understanding and engaging in CCKT activities within classrooms; and 3. Self-evaluating their own understanding and participation in CCKT activities. Table 2 summarizes the responses of the respondents for the above three sections. Only the four top-scored items are included here for the purposes of analysis.

Table 2

Responses With Top Scores for the CCKT Questionnaire

\begin{tabular}{|c|c|}
\hline \multirow{4}{*}{$\begin{array}{l}\text { Section 1: Understanding and engaging in } \\
\text { CCKT activities outside classrooms }\end{array}$} & 1. Meeting new friends and attending social events; \\
\hline & 2. Collaborating with peer learners in learning Chinese; \\
\hline & 3. Collaborating with local students in learning Chinese; \\
\hline & 4. Conversing and collaborating with teachers. \\
\hline \multirow{4}{*}{$\begin{array}{l}\text { Section 2: Understanding and engaging in } \\
\text { CCKT activities within classrooms }\end{array}$} & 1. Practising listening and speaking skills in pairs or in groups; \\
\hline & 2. Practising reading and writing skills using self-chosen topics/books; \\
\hline & 3. Learning Chinese through playing games and fun activities; \\
\hline & 4. Listening to teacher's grammatical explanations. \\
\hline \multirow{4}{*}{$\begin{array}{l}\text { Section 3: Self-evaluating the understanding } \\
\text { and participation in CCKT activities }\end{array}$} & 1. To raise aspirations for further Chinese tertiary study; \\
\hline & 2. To enhance my own readiness for professional life; \\
\hline & 3. To attract possible funding, e.g., sponsorships, scholarships, etc.; \\
\hline & 4. To produce cultural engagements between different cultures. \\
\hline
\end{tabular}

We can see that the responses for Section 1 center on items that render around the collaborative nature or participating in groups, either in small groups with peers or in bigger groups during social events. This result may mean: 1. The participants might have understood the term "CCKT" having an element of collaboration in it; 2. The participants of the study are learners from Asian background whose cultural norm is of collectivist society (Hofstede, 1980; 1986), in which people work in groups or teams to achieve the common benefits of the society; and 3. Language learning itself is a socialised learning process as, according to Brown and many other researchers, learning a second language often goes hand in hand with learning a second culture (e.g., Brown, 1980).

The results of Section 2 are surprisingly consistent with those found for Section 1. The participants tend to favour group activities in Chinese learning within classrooms, and believe such group activities tend to be more connected to CCKT. "Practising listening and speaking skills in pairs or in groups" stands out as the most likely 
activity that is relevant to CCKT. Their preference for learning about grammar in Chinese and practising reading and writing indicate the important role of grammar learning or "silent learning", which is more consistent with the way by which they were taught before in their home country and which is typical to Asian way of learning (Hofstede, 1986; Biggs \& Watkins, 1996). Participants' rating "Learning Chinese through playing games and fun activities" highly may mean that games and fun activities are generally favored by students in language learning. It can also mean that these participants enjoyed the Western way of learning which aims to achieve more communicative competence (Biggs \& Watkins, 1996), as games and fun activities are usually considered by applied linguistics as effective ways to achieve communicative capabilities.

Reading and writing were also favored activities, then grammatical explanations from the teachers. These activities have strong characteristics of traditional teaching and learning method and clearly these research participants still showed traces of the Eastern style of learning during learning Chinese language (Biggs \& Watkins, 1996).

In Section 3, where the participants evaluated their own understanding of and their participation in the CCKT activities both inside and outside classrooms, the results showed that "To enhance my own readiness for professional life", "To raise aspirations for further Chinese tertiary study", and "To produce cultural engagements between different cultures" clearly stand out as the highest response rate. The participants acknowledged the role of cultural engagement between different cultures nearly as important as their aspirations for Chinese learning in enhancing their professional life. According to Ipe (2003), one of the central factors impacting knowledge transfer is motivation. The most likely way of interpreting the results of Section 3 could be that the participants are both highly instrumentally and interactively motivated in Gardner's (1985; 1990) terms. It is important to note that the participants who were more motivated tended to show a higher level of awareness of the cultural and linguistic knowledge had a higher participation rate for the cross-cultural learning activities.

\section{Cultural Learning Styles and Engagement in Knowledge Transmission}

Correlation coefficients were calculated using the SPSS software to all the parameters tested by both questionnaires which have been employed for this research. Table 3 presents only those parameters that show or tend to show significant correlated outcomes.

Nationality is clearly positively correlated with participation in the CCKT activities $(r=0.387)$. This means that students from different cultures engaged in a larger number of knowledge transmission activities. The Vietnamese students, who were labeled with the highest value denominator in SPSS data spreadsheet, participated in more CCKT activities than Russian and Byelorussian students. The contributing factors for this difference could be many, including the availability of the activities and the way that the teaching was conducted.

There are no significant differences identified in the level of understanding of the cultural and linguistic knowledge. There are also no differences in the amount of time they spent on the activities that involve transmission and sharing of such knowledge.

The interesting result is that the students' course levels are highly positively correlated with Small/Large Power Distance $(r=0.437)$, which indicates that power distance is related to students' course level. In other words, the higher the students' level of Chinese proficiency, the smaller power distance they present. In other words, the more second language one acquires, in this case the Chinese language, the more Western style of learning one presents. 
Table 3

Correlation Between CLSI and CCKT

\begin{tabular}{|c|c|c|c|c|c|c|c|}
\hline & Nationality & Courses & $\begin{array}{l}\text { Course } \\
\text { levels }\end{array}$ & $\begin{array}{l}\text { Total score for } \\
\text { understanding } \\
\text { CCKT }\end{array}$ & $\begin{array}{l}\text { Total No. of } \\
\text { CCKT activities } \\
\text { participated }\end{array}$ & $\begin{array}{l}\text { Total } \\
\text { percentage in } \\
\text { the last } 12 \\
\text { months }\end{array}$ & $\begin{array}{l}\text { Collectivism } \\
\text { minus } \\
\text { Individualism }\end{array}$ \\
\hline \multirow{2}{*}{ Courses } & -0.088 & & & & & & \\
\hline & 0.617 & & & & & & \\
\hline \multirow{2}{*}{ Chinese course levels } & 0.205 & 0.132 & & & & & \\
\hline & 0.02 & 0.45 & & & & & \\
\hline \multirow{2}{*}{$\begin{array}{l}\text { Total score for } \\
\text { understanding CCKT }\end{array}$} & -0.118 & 0.245 & -0.164 & & & & \\
\hline & 0.501 & 0.157 & 0.346 & & & & \\
\hline \multirow{2}{*}{$\begin{array}{l}\text { Total no. of CCKT } \\
\text { activities participated }\end{array}$} & $0.387^{*}$ & 0.097 & 0.078 & 0.084 & & & \\
\hline & 0.022 & 0.578 & 0.658 & 0.633 & & & \\
\hline \multirow{2}{*}{$\begin{array}{l}\text { Total percentage in } \\
\text { the last } 12 \text { months }\end{array}$} & -0.015 & 0.027 & -0.129 & -0.127 & 0.128 & & \\
\hline & 0.93 & 0.876 & 0.462 & 0.468 & 0.464 & & \\
\hline \multirow{2}{*}{$\begin{array}{l}\text { Collectivism minus } \\
\text { Individualism }\end{array}$} & -0.199 & -0.08 & -0.133 & -0.111 & -0.279 & 0.065 & \\
\hline & 0.251 & 0.647 & 0.445 & 0.525 & 0.105 & 0.711 & \\
\hline \multirow{2}{*}{$\begin{array}{l}\text { Small Power Distance } \\
\text { minus Large Power } \\
\text { Distance }\end{array}$} & 0.085 & 0.147 & $0.437^{*}$ & 0.331 & -0.027 & -0.24 & -0.185 \\
\hline & 0.626 & 0.398 & 0.012 & 0.052 & 0.875 & 0.165 & 0.288 \\
\hline
\end{tabular}

Notes. ${ }^{*}$ Pearson correlation: Significant at the 0.05 level (2-tailed); ${ }^{* *}$ Pearson correlation: Significant at the 0.01 level (2-tailed)

\section{Findings and Discussion}

This study on the interaction of cultural learning styles and cross-cultural knowledge transmission has generated the following findings:

1. Chinese language learners coming from Asian countries have swung towards Western styles of learning while still leaving behind them a trail of their Eastern features of learning;

2. The longer one learns a second language, or the more proficient one gets in a second language, the more likely one learns towards the Western way of learning, at least in the dimension of Small/Large Power Distance;

3. There was a consistent understanding among the participating students that second language learning involves collective group work and they need to engage more in activities that are linguistically and culturally abundant in knowledge;

4. This is a group of motivated learners of Chinese language who are both instrumentally and integratively high in motivation.

The results of CLSI show that the participants demonstrated a considerable shift from their traditional norm of learning styles toward the Western styles of learning, but they were still significantly close to the top-right quadrant where their traditionally Asian norm of learning styles is located. Meanwhile, the results for CCKT show that the participants still maintain traces of collectivist way of learning in the process of their learning and knowledge sharing. It is not surprising that the participants moved towards a Western style of learning which has the characteristics of less formal and more communicative in this globalised learning context. This finding echoes the conclusion of Tobin et al. (1989) who, after conducting a study on Chinese pre-schools, claimed that in modern China, the emphasis on group collectivism against individualism is more theoretical speculation than empirically based assumption (Tobin et al., 1989). 
During the learning process, the participants see the collectivist aspect of learning as the preferred element in choosing learning activities. That is why their responses centered on items that carried the nature of collaborating in groups, either in small groups with peers in the classrooms or in bigger groups during social events. When it comes to learning the four skills of Chinese language-listening, speaking, reading, and writing-again working in groups and favoring reading and writing activities came out as the favored collectivist way of learning. In particular interest in grammar learning flared strong amongst other skills. Game activities are generally the favourites for language learners, but not the number one favorite for these particular participating Chinese learners. The reasons could be that these participants favored more reading, writing, and grammatical activities. However, this result can also mean that these activities were not readily available at the time when the research was conducted, which, by itself, could be an indication that the learning context in China is still more traditional and Eastern than people have recently anticipated ( $\mathrm{Li}, 2000$; Tweed \& Lehman, 2002; Rao, 2003).

No matter how the trend of Eastern and Western styles of learning is to play out, the tendency that the participants were "migrating" to the Western way of learning is also supported by the finding that the dimension of Power Distance is related to the amount of language one learns. In other words, the more Chinese language one learns, the more likely he/she is to feature a Western way of learning.

The interesting finding of this study also lies in the participants' understanding of the cultural and linguistic knowledge and its connection to language learning. The participants showed a consistently high level of acknowledgement of the role knowledge transmission and sharing can play in their Chinese learning (Ipe, 2003; Duan et al., 2010). They demonstrated willingness in participating in these activities during the process of their Chinese learning, though there still exists a variation between cultures in terms of the total number of activities they participated. Reasons that may contribute to this might again be the cultural environment in which learning and teaching happens, which could be explored in future studies.

The perceived purposes or values of learning Chinese can vary from one individual to another. To be engaged in cross-cultural activities and to learn Chinese language for future aspirations are what this group of learners would like to do, and they can be considered a group of motivated learners, both instrumentally and integratively (Gardner, 1985; 1990). This perhaps becomes a reason why learning Chinese language is associated with "linguistic capital" (Bourdieu, 1991) as this language can grant people a "passport" to operate in China, which is the world's second largest economy. Certainly, learning a second or foreign language can enhance students' career prospect due to its social value and the intercultural competence multilingual and multicultural knowledge can bring to them (Lo Bianco et al., 1999).

\section{Conclusion}

The findings of this study present to us a group of highly motivated Chinese language learners, who value the knowledge embedded in the Chinese language and culture, and are learning to adapt to the new styles of learning or new ways of thinking in order to be able to communicate effectively in the new language they are undertaking to learn. The study also shows that the participants of the study seemed to be on top of what this cross-cultural learning is about in terms of the linguistic and cultural knowledge involved and the way they can get engaged in the transmission and sharing of such knowledge.

The findings of this study can help us better understand the richness of knowledge that flows across cultures and the best possible ways that such knowledge can be learned and shared. Cross-cultural learning and 
sharing offers academics and students as well the chance to gain additional and often complementary knowledge, experience, and opportunities for language learning itself. The study can also inform the possibilities in sharpening the edges for future employment prospects for learners of the Chinese language and others, particularly when language learning is becoming more and more a community bearing economic value.

The power of cultural and linguistic knowledge could change our way of thinking, learning, and working. Thus, both language educators and students should present flexible thinking and possess broad cultural awareness so as to cope better as well as to surf freely with this cultural and linguistic diversity. The need for raising the awareness of the essential role of multicultural and multilingual knowledge with different cultural learning styles is getting paramount and indispensable for educators and students (Goh, 2002; Qing, 2008). How best to learn the language will eventually come down to bringing the linguistic and cultural knowledge into classroom practices, curriculum design and implementation, and education policy-making, and how such knowledge can be best obtained by students from various cultural backgrounds with different cultural learning styles.

\section{References}

Ardichvili, A., Maurer, M., Li, W., Wentling, T., \& Stuedmann, R. (2006). Cultural influences on knowledge sharing through online communities of practice. Journal of Knowledge Management, 10(1), 94-107.

Bengoa, D. (2013). Does national culture affect intercultural knowledge transfer? Proceedings of The International Conference on Intellectual Capital, Knowledge Management \& Organizational Learning (pp. 487-494).

Biggs, J., \& Watkins, D. (1996). The Chinese learner in retrospect. In D. Watkins, \& J. Biggs (Eds.), The Chinese learner: Cultural, psychological, and contextual influences (pp. 269-285). Hong Kong: Comparative Education Research Centre; Australia: The Australian Council for Educational Research.

Bourdieu, P. (1991). Language and symbolic power. Cambridge, U.K.: Polity Press.

Bresman, H., Birkinshaw, J., \& Nobel, R. (1999). Knowledge transfer in international acquisitions. Journal of International Business Studies, 30(3), 439-462.

Brown, H. (1973). Affective variables in second language acquisition. Language Learning, 23(2), 231-244.

Brown, H. (1980). Principles of language learning and teaching. Englewood Cliffs, N.J.: Prentice Hall.

Cameron, D. (2000). Good to talk? Living and working in a communication culture. London, U.K.: Sage.

Cameron, D. (2005). Communication and commodification: Global economic change in sociolinguistic perspective. In G. Erreygers, \& G. Jacobs (Eds.), Language, communication and the economy (pp. 9-25). Amsterdam: John Benjamins Publishing Co..

Canale, M. (1983). From communicative competence to communicative language pedagogy. In J. Richards, \& R. Schmidt (Eds.), Language and communication (pp. 2-27). London, U.K.: Longman.

Canale, M. (1984). A communicative approach to language proficiency assessment in a minority setting. In C. Rivera (Ed.), Communicative competence approaches to language proficiency and assessment: Research and application. Clevedon, Avon: Multilingual Matters.

Canale, M., \& Swain, M. (1980). Theoretical bases of communicative approaches to second language learning and testing. Applied Linguistics, 1, 1-47.

Chen, S. (1990). A study of communication strategies in interlanguage production by Chinese EFL learners. Language Learning, 40(2), 155-187.

Chini, T. C. (2004). Effective knowledge transfer in multinational corporations. New York, N.Y.: Palgrave Macmillan.

Cope, B., \& Kalantzis, M. (2000). Cultures of schooling: Pedagogies of cultural difference and social access. Basingstoke: Falmer Press.

Duan, Y. Q., Nie, W. Y., \& Coakes, E. (2010). Identifying key factors affecting transnational knowledge transfer. Information and Management, 47, 356-363.

Dunn, R., \& Griggs, S. (1988). Learning styles: Quiet revolution in American schools. Reston, V.A.: National Association of Secondary School Principals. 
Ellis, R. (1997). Second language acquisition. Oxford, U.K.: Oxford University Press.

Erreygers, G., \& Jacobs, G. (Eds). (2005). Language, communication and the economy. Amsterdam: John Benjamins Publishing Co..

Friedman, J. (1994). Cultural identity and global process. London, U.K.: Sage.

Gardner, R. (1985). Social psychology and second language learning: The role of attitudes and motivation. London, U.K.: Edward Arnold.

Gardner, R. (1990). Attitudes, motivation, and personality as predictors of success in foreign language learning. In T. Parry, \& C. Stansfield (Eds.), Language aptitude reconsidered (pp. 179-221). Englewood, N.J.: Prentice Hall.

Goh, S. C. (2002). Managing effective knowledge transfer: An integrative framework and some practice implications. Journal of Knowledge Management, 6(1), 23-30.

Goodenough, D. (1976). The role of individual differences in field dependence as a factor in learning and memory. Psychological Bulletin, 83(4), 675-694.

Haghirian, P. (2011). Multinationals and cross-cultural management: The transfer of knowledge within multinational corporations. New York, N.Y.: Routledge.

Hedlund, G. (1994). A model of knowledge management and the N-form corporation. Strategic Management Journal, 15(Summer Special Issue), 73-91.

Hedlund, G., \& Nonaka, I. (1993). Models of knowledge management in the West and Japan. In P. Lorange, B. Chakravarthy, J. Roos, \& A. Van de Ven (Eds.), Implementing strategic processes: Change, learning, and cooperation. Oxford, U.K.: Blackwell.

Heller, M. (1999). Linguistic minorities and modernity: A sociolinguistic ethnography. London, U.K.: Longman.

Hofstede, G. (1980). Culture's consequences-International differences in work-related values. Beverly Hills, C.A.: Sage Publications.

Hofstede, G. (1986). Cultural difference in teaching and learning. International Journal of Intercultural Relations, 10, 301-320.

Hofstede, G. (2001). Cultures consequences: Comparing values, behaviours, institutions and organisations across nations (2nd ed.). London, U.K.: Sage.

Hofstede, G., \& Hofstede, G. J. (2005). Cultures and organisations: Software of the mind-Intercultural cooperation and its importance for survival. London, U.K.: McGraw-Hill.

Holden, N. J. (2002). Cross-cultural management: A knowledge management perspective. London, U.K.: Prentice Hall.

House, R. J., Hanges, P. J., Javidan, M., Dorfman, P. W., \& Gupta, V. (2004). Culture, leadership and organisations: The GLOBE study of the 62 societies. Thousand Oaks, C.A.: Sage Publications Inc..

Howard, J. (2005). The emerging business of knowledge transfer: Creating value from intellectual products and services (Report of a study commissioned by the Department of Education, Science and Training). Canberra: Howard Partners.

Ipe, M. (2003). Knowledge sharing in organizations: A conceptual framework. Human Resource Development Review, 2(4), 337-359.

Joy, S., \& Kolb, D. (2009). Are there cultural differences in learning styles? International Journal of Intercultural Relations, $33(1), 69-85$.

Keefe, J. (1979). Learning style: An overview. In J. Keefe (Ed.), Student learning styles: Diagnosing and prescribing programs (pp. 1-17). Reston, V.A.: National Association of Secondary School Principals.

Keefe, J. (1987). Learning style theory and practice. Reston, V.A.: National Association of Secondary School Principals.

Kogan, N. (1971). Educational implications of cognitive styles. In G. Lesser (Ed.), Psychology and educational practice (pp. 242-292). Glenview, I.L.: Scott Foresman.

Kolb, D. (1976). Learning style inventory technical manual. Boston, M.A.: McBer.

Kommers, J., \& Venbrux, E. (Eds.). (2008). Cultural styles of knowledge transmission: Essays in honour of Ad Borsboom. Amsterdam: Aksant.

Li, L. (2000). Grouping practices and individual differences in adult ESL programs-With special reference to high English language achievers (Unpublished Ph.D. dissertation, RMIT University, Melbourne).

Li, L. (2012). Internationalizing university curriculum with multilingual knowledge and skills: Power, politics and policy. Local Global Journal of Sustainability, Security and Community, 9, 44-59.

Lo Bianco, J., Liddicoat, A. J., \& Crozet, C. (Eds.). (1999). Striving for the third place: Intercultural competence through language education. Melbourne: Language Australia.

Merritt, A. (2000). Culture in the cockpit: Do Hofstede's dimensions replicate? Journal of Cross-Cultural Psychology, 31(3), 283-301. 
Myers, I. B., McCaulley, M. H., Quenk, N. L., \& Hammer, A. L. (1998). MBTI manual: A guide to the development and use of the Myers Brigg type indicator (3rd ed.). Palo Alta, C.A.: Consulting Psychologists Press.

Nonaka, I., \& Takeuchi, H. (1995). The knowledge-creating company. New York, N.Y.: Oxford University Press.

Nunan, D. (1988). The learner-centred curriculum. Cambridge, U.K.: Cambridge University Press.

Oxford, R. (1990). Language learning strategies: What every teacher should know. New York, N.Y.: Newbury House Publishers.

Park, J. S. Y., \& Wee, L. (2013). Markets of English: Linguistic capital and language policy in a globalizing world. New York, N.Y.: Routledge.

Phillipson, R. (1992). Linguistic imperialism. Oxford, U.K.: Oxford University Press.

Phillipson, R. (2002). Global English and local language policies. In A. Kirkpatrick (Ed.), English in Asia: Communication, identity, power and education (pp. 7-28). Melbourne: Language Australia.

Qing, X. (2008). The culture relativity in the knowledge flow: An integrative framework in the Chinese context. Chinese Management Studies, 2(2), 109-121.

Rao, Z. H. (2003). Bridging the gap between teaching and learning styles in East Asian contexts. TESOL Journal, 11(2), 5-10.

Reid, J. (Ed.). (1995). Learning styles in the ESL/EFL classroom. Boston, M.A.: Heinle \& Heinle.

Robinson, S. (2010). The role of higher education institutions in knowledge transfer and exchange: Exploring social processes. Bradford: Emerald Group Pub..

Sapir, E. (1921). Language: An introduction to the study of speech. New York, N.Y.: Harcourt and Brace.

Smith, L. M. (2012). Knowledge transfer in higher education: Collaboration in the arts and humanities. Houndmills, Basingstoke, Hampshire, and New York: Palgrave Macmillan.

Tobin, J., Wu, D., \& Davidson, D. (1989). Preschool in three cultures: Japan, China, and the United States. New Haven, C.T.: Yale University Press.

Tweed, R., \& Lehman, D. (2002). Learning considered within a cultural context: Confucian and socratic approaches. American Psychologist, 57(2), 89-99.

Whorf, B. (1956). Language, thought, and reality. Cambridge, M.A.: MIT Press.

Willing, K. (1993). Learning styles in adult migrant education. Sydney, Australia: National Centre for English Language Teaching and Research, Macquarie University.

Willing, K. (Ed.). (1998). Understanding learning styles in the second language classroom. Englewood, N.J.: Prentice Hall.

Witkin, H. (1976). Cognitive style in academic performance and in teacher-student relations. In S. Messick, \& Associates (Eds.), Individuality in learning (pp. 38-72). San Francisco, C.A.: Jossey-Bass.

Witkin, H., \& Goodenough, E. (1977). Field dependence and interpersonal behaviour. Psychological Bulletin, 84(4), 661-689. 